\title{
CHRISTOPHER ST GERMAN: \\ RELIGION, CONSCIENCE AND LAW IN REFORMATION ENGLAND \\ Ian Williams*
}

Christopher St German, a barrister and writer, has attracted considerable attention from historians. His work known as Doctor and Student provides evidence of common law practice and rules around 1500, but for legal historians is usually more significant as a serious attempt to provide a coherent and complete theory of English law. In particular, St German seems to have introduced the language of equity into English law and provided a theory of the equity jurisdiction based around conscience. This set the parameters for future discussions of the nature of equity in the common law tradition.

St German has also been of considerable interest to non-legal historians. Doctor and Student, and St German's later writings, are associated with the Henrician reformation and the controversy it engendered. St German is sometimes seen as providing important intellectual support for the developments of the early-1530s, especially the break from Rome itself. From this perspective, St German is considered more as a political thinker, concerned with the relations between Church and State.

This chapter shall focus on Doctor and Student as St German's principal juristic writing. However, a new perspective shall be put forward, arguing that we should see Doctor and Student not just as a juristic and political work, but much more as a religious one. The argument here is that to focus on St German as a jurist is to overlook important aspects of his work. Doctor and Student had juristic content and

\footnotetext{
" Lecturer, Faculty of Laws, UCL. My thanks to the participants in this volume's colloquium for their comments on the chapter.
} 
clearly a juristic afterlife, but that was not St German's primary purpose in writing and printing it.

\section{ST GERMAN'S LIFE}

Christopher St German lived longer in obscurity than many of the other individuals in this volume lived at all. Probably born around 1460 to a minor gentry family in Warwickshire, details of St German's life until the late-1520s are lacking. ${ }^{1}$ No evidence of his legal or non-legal education exists. He made his way to London, probably in his mid-late teens, became a member of the Middle Temple (perhaps after membership in an Inn of Chancery) and a barrister. His (extended) family and fellow Templars seem to have comprised most of his social and other contacts for most of his life. John Guy has painstakingly drawn together the very limited evidence about St German's life. ${ }^{2}$

St German's career as a barrister was undistinguished. The first mention of St German in any historical sources is in the records of the Middle Temple for 1502, when St German was probably already in his early forties. He was still an 'utter barrister' and he never progressed to membership of the Bench of his Inn. There is sparse evidence for St German's legal practice. Status as an utter barrister denied lawyers audience rights in the Court of Common Pleas, the most important of the central common law courts, and so it is no surprise that St German does not appear as a lawyer in any contemporary law reports.

\footnotetext{
${ }^{1}$ St German's birth around 1460 is inferred from Bale's claim that St German was about eighty when he died (John Bale, Scriptorum illustrium maioris Brytannie (1557-1559, Basel, Johannes Oporin), p.660). However, various aspects of Bale's biography are questionable, and the known evidence of St German's legal career is not incompatible with his birth being up to a decade later.

2 For the biographical material in this chapter, see generally Guy, Christopher St German on Chancery and Statute (1985, London, Selden Society Supplementary Series vol.6), pp.1-55.
} 
Some aspects of his practice can be traced in other records. In 1505 St German was involved in the Court of Requests in a dispute between family members about inherited property. It is not clear whether St German was counsel for one of the parties, or appointed as an independent actor - together with another barrister he was to gather all the family's relevant deeds and other documents and distribute them to those family members best entitled to them. In 1508 and 1510 he was involved, with other Middle Templars, as one of several feoffees of land, to hold to the use of others. By the early-sixteenth century, placing land in use (the precursor to the trust) was a means by which landowners could avoid some of the undesirable financial consequences of English feudal land law and groups of lawyers were frequently appointed as the feoffees (legal owners) for these purposes. All of the evidence of St German's practice, like that of many other lawyers, suggests a regional component. These three records relate to land in Staffordshire, Warwickshire and Nottinghamshire, all in the Midlands and no more than forty miles from St German's birth parish of Shilton.

St German disappears from the records of the Middle Temple after 1511 and a remark in a 1539 letter suggests that he left the Temple before about 1515 . There is no evidence of further remunerated legal practice, although St German did continue to provide some services for family members, such as acting as an executor. He also lent money to a cousin's widow. St German seems not to have inherited his family's property in Shilton, eventually renting and then owning land in Alvechurch, Worcestershire (again, less than forty miles from Shilton). For much of his life he lived in London and from 1527 the Alvechurch property was rented to a cousin. By 1540 he was living in a rented house in Old Fish Street in London, a little south of St Paul's.

That location must have been desirable for St German. Although some distance from the Inns, the area around St Paul's was an important one for the early-modern 
English book trade, and St German was described by John Bale as leaving most of his wealth in books. St German certainly was a keen reader, especially of religious works. In a 1539 letter to Thomas Cromwell, Henry VIII's chief minister, the nearly eighty year old St German apologises for his inability to visit Cromwell personally, observing that 'I am not able to it'. While the elderly St German could not manage that journey, he remained a bibliophile. The letter is directed to a matter of business, but St German's final, telling, remark concerns his ongoing search for books, 'And I can not gette any of the bokes of Erasmus de Sarcerio de Locus Communibus' ${ }^{3}$ This is a reference to the Commonplaces of Scripture, translated by Richard Taverner (whose protestant leanings can be seen by his role as a lay preacher during the reign of Edward VI). ${ }^{4}$ St German regarded his books as both his most valuable and most desirable possessions. In his will, he directed his executor to sell assets from the estate to pay his bequests, a typical instruction. Very unusually, the executor was first directed to sell St German's books, together with the right to take books from St German's collection for himself, paying a fair price.

St German was not just a reader of books, but a producer of them. His first foray into the world of publishing was in the first decade of the sixteenth century when, in combination with two other Middle Templars, he entered into an agreement with the printer Richard Pynson for the reprinting of Pynson's Abridgement of the Statutes, a work of almost two hundred folios which arranged statutes under alphabetical subject-matter titles. ${ }^{5}$ The arrangement did not proceed as well or as happily as planned, and ended in litigation in the common law courts and the Chancery. No outcome to the dispute is known and no copies of this printing of the Abridgement are known to exist.

\footnotetext{
3 TNA: PRO SP 1/152, fo.249.

4 Erasmus Sarcerius (Richard Taverner, trans.), Common places of Scripture ordrely and after a compendious forme of teachyng set forth (1538, London, John Byddel) STC (2nd ed.) 21752.5.

${ }^{5}$ Abbreuiamentum statuorum (1499, London, Richard Pynson) STC (2nd ed.) 9514.
} 
It was not as a publisher, and certainly not as a lawyer, but as a writer that St German became famous. Despite his seeming retirement in the second decade of the sixteenth century, St German embarked on a new career as a prolific author a few years before turning seventy. His first book, and the one on which his description as a 'jurist' is principally based, is known as Doctor and Student and was first printed in 1528. ${ }^{6}$ It seems to have been sufficiently impressive to lead Cardinal Wolsey to appoint St German to a role in the Court of Requests in 1529, although there is no evidence St German ever sat. He continued to write until at least 1537 (the last year for which extant writings survive), dying in London in 1541.

\section{ST GERMAN'S RELIGIOUS VIEWS}

Our knowledge of St German's religious views are drawn principally from four sources: two unpublished manuscripts which he sent to Thomas Cromwell in 1537; St German's comments on the 1537 Bishops' Book (solicited by Thomas Cromwell) and his will. ${ }^{8}$ All of these are from late in his long life. The first manuscript, a 'Discourse of the Sacraments' relates to debates in England in 1537 about the number of sacraments. ${ }^{9}$ The second manuscript continues the dialogue between the Doctor of theology and the Student of the laws, begun in Doctor and Student, now as a 'Dialogue showing what we be bound to believe as things necessary to Salvation, and what not'.10

\footnotetext{
${ }^{6}$ T.F.T Plucknett and J.L Barton (eds.), St German's Doctor and Student (1974, London, Selden Society volume 91). There are persistent claims of a 1523 edition, but there are no known copies or contemporary evidence for this.

7 The institution of a Christen man, conteynynge the exposition or interpretation of the commune Crede, of the seuen sacramentes, of the $x$. commandementes, and of the Pater noster, and the Aue Maria, justification and purgatorie (1537, London, Thomas Berthelet), STC (2nd ed.) 5164-5167.

8 TNA: PRO PROB 11/28/511.

${ }^{9}$ TNA: PRO SP 6/8, pp.1-20.

${ }_{10}$ TNA: PRO SP 6/2, pp.89-168.
} 
In 1536, predating all of these sources, St German's writings were described in the articles of the Pilgrimage of Grace as 'heresies' needing to be 'annulled and destroyed'.11 St German's books were associated with Tyndale, and other heresies identified in the article include those of Wycliffe, Huss, Luther and Zwingli. From the perspective of the Protestant tradition, St German was keeping impressive company. It seems likely St German would have been disappointed with these associations. Although the sources from late in his life present a somewhat mixed picture, there were clear differences between the views of St German and those of people identified as Protestants, such as Luther and Zwingli.

St German was clearly not an ardent follower of Luther. His written works show considerable reliance on the Summa Angelica, a work which Luther had burned in December $1520 .{ }^{12}$ More significantly, the two 1537 manuscripts show that St German rejected the Lutheran idea of a priesthood of all believers. For St German the priesthood continued to have a vital sacramental role and priests were in that way different to other people. No one else, not even the King, could exercise certain sacramental roles, such as consecration. St German also retained a firm belief in transubstantiation, rejecting alternatives presented by Protestants. Prayers for the souls of the dead were effective, and St German made provision for such prayers for his soul and those of his parents in his own will. The saints also continued to have an intercessory role, although St German was concerned that this should not be amplified. ${ }^{13}$ These beliefs, together with a belief in the Trinity, the perpetual virginity of Mary and the contents of the Apostles' Creed were all within medieval orthodoxy.

\footnotetext{
${ }^{11}$ James Gairdner (ed.), Letters and Papers, Foreign and Domestic, of the Reign of Henry VIII (1888, London, HMSO), vol.11, p.506 (no.1246).

${ }^{12}$ Letter to George Spalatin, 10 December 1520, pp.186-187 in Gottfried G. Krodel (ed. and trans.), Luther's Works, vol.48 Letters I (Fortress Press, Philadelphia, 1963).

${ }^{13}$ St German disagreed here with Henry VIII. The Bishops' Book referred to Christ as the only mediator, but that this did not preclude the intercession of saints. Henry wished to change this to the 'mediation' of saints, while St German wished to maintain the original 'intercession', on the basis that Henry's amendment would set 'the saints in more estimation' (Guy, St German on Chancery and Statute, p.54).
} 
A parliamentary draft attributed by Guy to St German also supports a vernacular New Testament. This was not a particularly Protestant position and had support within the Catholic Church too. St German's support was also not unequivocal. A vernacular New Testament was only to be supported if the demand for it flowed from 'meekness and charity', reflecting contemporary concerns that vernacular scriptures could be used to undermine existing beliefs and authority. ${ }^{14}$

St German rejected any role for religious tradition in determining what was necessary for salvation and largely rejected the Church Councils of the past. Instead, St German regarded Scripture alone as the basis for determining Christian doctrine and Scripture was only to be interpreted literally. ${ }^{15}$ Doctrine could be found not just from the words of Scripture, but also what 'may be derived out thereof in a probable consequence' ${ }^{16}$ St German's justification for relying on Scripture but not the views of doctors of the church for determining doctrine was not like most Protestants. It was not normative but evidential; he thought that it could not be certain whether or not writings attributed to doctors were actually their work. ${ }^{17}$ St German recognised a need for someone to be able to determine doctrine authoritatively and he seems to have accepted that even allowing only literal interpretation might not achieve this. He changed his views on how a single correct interpretation of Scripture was to be achieved over the 1530s, locating that authority in various groups (although consistently away from the clergy alone). ${ }^{18}$ While a rejection of tradition was a strand within late-medieval Catholic theology, by 1537 St German's religious views were

\footnotetext{
${ }^{14}$ Guy, St German on Chancery and Statute, p.127.

15 TNA: PRO SP 6/2, p.117; TNA: PRO SP 6/8, pp.13-16 (where literal interpretation is the basis for St German's belief in transubstantiation).

16 TNA: PRO SP 6/2, p.89.

17 TNA: PRO SP 6/2, p.90.

${ }_{18}$ The most detailed account is Daniel Eppley, Defending Royal Supremacy and Discerning God's Will in Tudor England (2007, Ashgate, Aldershot), pp.80-119.
} 
importantly heterodox. ${ }^{19}$ Crucially, he denied the status of marriage and penance as sacraments. ${ }^{20}$

\section{ST GERMAN THE AUTHOR}

By the time of his death, nine of St German's works had been printed. A parliamentary draft, two religious manuscripts and a work on the Chancery all survived in manuscript, with the Chancery work being printed in 1787 as A Little Treatise concerning Writs of Subpoena and his parliamentary draft in 1985. St German may also have been the author of another manuscript, seemingly written in reply to St German's own work on conscience. ${ }^{21}$ For a man in his eighth decade of life, this is an impressive display.

Several of St German's publications in the 1530s were printed by the King's Printer, Thomas Berthelet, and this suggests a link with the government, even that St German was working for Henry VIII's government in forming opinion about the developments of the 1530s. However, St German seems to have retained his independence from the government. He declined a request for assistance from writers working for Thomas Cromwell in 1534. It seems more likely that he was someone whose learning Cromwell respected, and whose ideas Cromwell found useful. This is corroborated by Cromwell seemingly soliciting St German's views about the Bishop's Book, suggesting that it was Cromwell who sought the link with St German, rather than the other way around.

\footnotetext{
${ }^{19}$ The links between St German's views and late-medieval theology have not yet been investigated. For example, St German's views on the role of tradition seem to indicate a departure from a reliance on Gerson in his thinking (for Gerson, see Heiko Oberman, The Harvest of Medieval Theology: Gabriel Biel and Late Medieval Nominalism (1963, Cambridge, Harvard University Press), pp.385-7).

${ }^{20}$ TNA: PRO SP 6/8, pp.2 (marriage) and 4 (penance).

${ }^{21}$ For these publications, see Guy, St German on Chancery and Statute, 16-17.
} 
Although there are close links between many of St German's writings, his place in this volume is based on his more legal writings. These appeared at the beginning of his career as an author and in many respects laid the foundations for future works. The First Dialogue of what would come to be known as Doctor and Student appeared in Latin in 1528 (an English version appearing in 1531), the Second Dialogue in 1530 and the New Additions to the dialogue in 1531. Doctor and Student went through eleven printings of the combined two dialogues in the sixteenth century and a further eleven in the seventeenth, with handfuls in the eighteenth and nineteenth centuries. By way of comparison, there were nine printings of Edward Coke's Commentary on Littleton, a rapidly accepted authoritative work, in the seventeenth century. In early-modern legal publishing terms, Doctor and Student was a bestseller. It was also read. Citations of Doctor and Student in court can be found into the 1670s, almost a century and a half after its initial publication. ${ }^{22}$ Its availability in English made Doctor and Student an accessible student work. St German's intellectual contribution in these works will be considered below.

Not all of St German's writings were so well-received. His Treatise concerning the Division between the Spiritualty and Temporalty ${ }^{23}$ provoked a response by the later canonised Thomas More, leading to what has been described as a 'battle of the books' between the two closely connected men. ${ }^{24}$ After St German was answered by

\footnotetext{
${ }^{22}$ Haughton $v$ Wilson (1673) 3 Keble 203, 204; 84 ER 677.

${ }^{23}$ A treatise concernynge the diuision betwene the spiritualtie and temporaltie (1532, London, Thomas Berthelet and Robert Redman) STC (2nd ed.) 21586-21587.7; modern edition in J.B. Trapp (ed.), The Complete Works of St. Thomas More, vol.9 (1979, New Haven, Yale University Press), pp.173-212.

${ }^{24}$ John Guy, 'Thomas More and Christopher St German: The Battle of the Books', pp. 95-120 in Alistair Fox and John Guy, Reassessing the Henrician Age: Humanism, Politics and Reform 1500-1550 (1986, Oxford, Basil Blackwell). More's brother-in-law was John Rastell, a lawyer who had been appointed as a feoffee with St German in 1508 and who later became a law printer, printing the 1528 edition of Doctor and Student. The Rastell family was connected with Coventry, near St German's own family home.
} 
More, St German responded with a new dialogue, Salem and Bizance, ${ }^{25}$ to which More replied; St German composed The Additions of Salem and Bizance as a further response. ${ }^{26}$ The battle then petered out, but St German is one of few authors whose works can accurately be described as having tried the patience of a saint.

The publications to which More took exception were anti-clerical. St German attacked what he perceived to be clerical abuses, both in performing their religious functions and in the church courts. A particular target was the investigation, trial and punishment of heretics, St German complaining about the use of inquisitorial process. For St German, the underlying problem was that men of God were men, with all the flaws and fallibility that implied. As men, priests were capable of sin, vulnerable to conflicts of interest and capable of abusing their power. More responded forcefully, not just to defend the church, but also his own reputation; More had been a vigorous participant in the detection of heretics while Lord Chancellor. These works by St German were not directly juristic, although his claims of procedural unfairness in, and understanding of, inquisitorial process probably reflect the views of someone more familiar with common law process than the nuances of ius commune procedure.

\section{ST GERMAN THE JURIST}

Although the main use of St German's writings in court was to provide cases for lawyers to put in the same manner as actual curial discussions and decisions, his principal contributions to English law were more jurisprudential. St German not only set out a theory of English law, he also provided the first theory to justify both

\footnotetext{
${ }^{25}$ Salem and Bizance (1533, London, Thomas Berthelet) STC ( $2^{\text {nd }}$ ed.) 21584; modern edition J. Guy, R. Keen, C.H. Miller and R. McGugan (eds.), The Complete Works of St. Thomas More, vol.10 (1987, New Haven, Yale University Press), pp.325-392.

${ }^{26}$ The addicions of Salem and Bizance (1534, London, Thomas Berthelet) STC (2nd ed.) 21585.
} 
the intervention of the Chancery in what came to be known as 'equity' in general, and its application in specific cases. ${ }^{27}$

St German's legal theory was in many respects unoriginal. He used widely accepted ideas from European legal theory. St German explained that the laws of England were several: the law of God, the law of reason (which seems to have been the same as the law of nature) and the various types of human law (general customs and maxims, as well as legislation). ${ }^{28}$ These various types of law were generally compatible. St German was very clear that human law could not be incompatible with either the law of God or the law of reason. Any human law incompatible with these higher laws would be void. There was nothing controversial in this in terms of late-medieval European legal theory.

St German's discussion of equity was derived from the French theologian, Jean Gerson, who made considerable use of Aristotle's discussion of epieikeia, although often used the Latin aequitas (equity) interchangeably with it. In fact, St German's discussion in Doctor and Student is often taken more or less verbatim from Gerson's work, ${ }^{29}$ and it is the conflation of epieikeia and aequitas which leads to descriptions of the Chancery as a court of 'equity'.

The medieval theory of epieikeia which St German used in Doctor and Student was premised on the observation, taken from Aristotle, that human laws framed in general terms would inevitably fail to achieve their objects in the infinite variety of circumstances to which they might be applied. In such cases, the failings of human law could be redressed by application of the intention of the legislator. Medieval

\footnotetext{
${ }^{27}$ For what follows, see especially Barton, 'Introduction' in Doctor and Student, pp.xi-lxvii.

${ }^{28}$ Although St German's language of 'maxims' might have been less comprehensible to civilians - he did not use the familiar civilian language of regulae iuris (Doctor and Student, p.57).

${ }^{29}$ Zofia Rueger, 'Gerson's Concept of Equity and Christopher St. German' (1982) 3 History of Political Thought 1-30.
} 
theologians applied this to the laws of God and nature. Gerson, and through him St German, took this further in its application to human laws. Human law makers would not have intended for their creations to be contrary to the law of God or the law of nature (or reason, on the Student's description of English law) - no law maker would have intended to create void law. If a human law therefore caused an outcome contrary to the law of God or the law of nature in a particular case, it followed that this was not what the law maker intended. To apply the outcome mandated by the law of God or nature would be to reach the result intended by the law maker.

St German was clear that in some cases, at least, just such an approach could be taken in common law courts. But in many instances the common law judges were required to follow the common law, law which was generally compatible with the laws of god and nature, but might produce an incorrect outcome in a particular case before the judges. In such cases, recourse could be had to the Chancery, via a subpoena. In such cases, the Chancery would be fulfilling the underlying intention behind the common law. Chancery provided equity to support, not undermine, the law.

Before St German, the Chancery is normally described as proceeding according to 'conscience'. ${ }^{30}$ St German's work did little to change this, instead bringing the two concepts of equity and conscience together, so that the Chancery as a provider of equity would be acting in accordance with conscience. While St German justifies the role of the Chancery in general in terms of equity, the Chancery's interventions in specific cases are described as the application of conscience.

${ }^{30}$ (1469) YB Trin 9 Edw.4, f.14, pl.9, per Stillington LC. 
St German's theory of conscience, like the components of his legal theory, was also derived from orthodox medieval theology. According to this theology, all human beings had the faculty of synderesis, 'moving and steering it to good and abhorring evil' ${ }^{31}$ Although synderesis itself could never be extinguished, its exercise might be overcome by error (such as someone incorrectly believing evil to be good) or obstinacy. Good and evil were not subjective, but determined by revelation and reason. Identifying what was good or evil therefore required knowledge of law. The Laws of God and Nature would often identify what was good or evil. Because the temporal authorities 'have received of god power to make laws', their laws were also considered to 'be made by god' ${ }^{32}$ As the Doctor later observed 'all laws made by man which be not contrary to the law of god must be observed and kept and that in conscience. And he that despises them despises god.'33

Conscience, in the strict sense, was not this knowledge of good or evil, but the application of this knowledge to particular facts to generate rules of conduct. Conscience was applied knowledge, 'the judgement of practical reason judging on the particular acts of man'. As St German noted on several occasions, in combination with his understanding of synderesis, 'conscience must always be grounded upon some law', whether divine, natural or human. ${ }^{34}$ This meant that human law took effect in conscience, unless, on particular facts, the Laws of God or Nature (themselves both coming directly from God, and therefore demanding obedience) required a different outcome.

St German described this mode of reasoning in conscience in the terms of formal logic:

\footnotetext{
31 Doctor and Student, p.81.

32 Doctor and Student, p.111.

33 Doctor and Student, p.147.

${ }^{34}$ Doctor and Student, pp.133, 163, 207.
} 
the syllogism of conscience in this manner: synderesis ministers the major thus: Rightwiseness is to be done to every man. Upon which major the law of England ministers the minor thus: the inheritance belongs to the son born after spousals. The conscience makes the conclusion and says therefore the inheritance is in conscience to be given to the son born after spousals. And so in other cases infinite may be formed by the law the syllogism or the right judgment of conscience. ${ }^{35}$

As with all formal logic, provided the premises and reasoning were correct, the correct conclusion in conscience would inevitably follow. St German recognised, however, that conscience, like synderesis, was not infallible. Conscience could err, 'led astray by passion, or through ignorance, or through a wrong and evil disposition'. ${ }^{36}$ Such erring consciences would need to be corrected. This had long been a justification for the church courts' activities in various spheres, but the role of human law meant that secular courts would also be involved in the regulation of conscience.

St German's model of conscience brought together the theory of equity and that of conscience. Equitable intervention occurred where human law would lead to an outcome contrary to the laws of God or nature (or reason) on particular facts. Identifying what the laws of God, nature or man required on particular facts was an act of reasoning that was conscience. The Court of Chancery was a court of equity because it used conscience to ensure that the human law of the common law did not lead to outcomes contrary to the laws of God or nature, outcomes which the common law wished to avoid but sometimes could not.

\footnotetext{
${ }^{35}$ Doctor and Student, p.129.

${ }^{36}$ Doctor and Student, p.91.
} 
Within this theory, St German (like Gerson) defined the law of God narrowly, denying that much of the law of the Church was in fact divine law. ${ }^{37}$ He was also clear that the entire law of property, and all law affecting property, was ultimately human law. There was no divine or natural law of property. This was not an especially controversial premise. Aquinas recognised that while natural law recognised the need for a law of property, it did not determine that law, which was a matter for human regulation. ${ }^{38}$ St German's position was the same. It followed that property rights were governed by human law and courts applying that law. For St German, this also meant that contract was similarly governed by human law, as contracts were about distributing property and so could not have existed without human property law. As the Doctor observed, 'contracts be not grounded upon neither of those laws but upon the law of man'. ${ }^{39}$ This did not mean that the Chancery was not involved with contractual matters, but that its intervention in this context was not about fulfilling the laws of God or nature.

The example which came to be the paradigm for early-modern explanations of the Chancery jurisdiction was the first specific case of conscience discussed by St German and did in fact relate to the law of contract. ${ }^{40}$ At common law, if one party entered into a sealed bond (an obligation) saying that they owed money to another (perhaps if certain circumstances were fulfilled), the debtor was strictly liable on the debt. The only available defences once the money was due were either to show that the bond itself had been cancelled, or produce another sealed document stating that the debt had been paid (an acquittance). This meant that if a debtor paid the creditor, but failed to obtain (or lost) an acquittance, the creditor could sue the debtor and at common law the debtor would be required to pay again. Common lawyers knew

\footnotetext{
${ }^{37}$ St German's law of reason secondary also introduced human law as an element in the law of reason, again limiting the scope for an independent law of reason to act as the basis for Chancery intervention.

${ }^{38}$ Summa Theologiae 2a2ae.66.2.

${ }^{39}$ Doctor and Student p.133.

${ }^{40}$ Doctor and Student pp.76-79
} 
this was not the desirable outcome; had the case been brought for a debt owed on an informal contract, prior payment would be a good defence. However, they were constrained by the evidential rules of the common law to require the debtor to pay twice where there was a sealed bond.

This was an excellent demonstration of the role of epieikeia. As the Student observed, in general the requirement of strong evidence of the discharge of a debt was a good one, given that the debt was also proved by strong evidence. The common law here 'sets a general rule which is good and necessary to all the people'. After explaining this, the Student said that the debtor can be aided by conscience. It is this discussion which begins St German's discussion of the nature of conscience itself. According to the Doctor, double payment was contrary to the law of reason and therefore also contrary to conscience. ${ }^{41}$ The Student agreed, but also made it very clear that 'it is not the law of England' that double payment is required, as that would be contrary to the law of reason. Chancery intervention not only satisfied conscience, it also fulfilled the underlying intention behind the common law, as the doctrine of epieikeia would suggest.

St German's theory of equity and conscience had several important consequences. In the context of the Reformation, St German's model was a challenge to claims by the Church and its courts to adjudicate matters of conscience. For many such issues, at least when connected with St German's broad view of what constituted purely temporal matters, conscience could only be determined through an understanding and application of English law. Limitations similar, but not identical, to those St German advocated had in fact largely been achieved (at least from the point of view of common lawyers) in the late-fifteenth and early-sixteenth centuries. ${ }^{42}$ More

\footnotetext{
${ }^{41}$ Doctor and Student, p.77.

42 J.H. Baker, Oxford History of the Laws of England, Vol.VI: 1483-1558 (2003, Oxford University Press, Oxford), pp.237-243.
} 
generally, and advocated more strongly in the New Additions and his other writings, St German's theory developed into a strong claim for secular control over many issues previously addressed by the Church.

Within the context of English legal history, St German's model led to a Chancery which was not an arbitrary court. It applied law of various types, all of which people could learn, and a reasoning process which was theoretically available to all human beings to produce entirely predictable outcomes. Crucially, the role of human law in determining conscience in many cases also meant that the Chancery's role was limited. If the Laws of God and Nature were indifferent as to the outcome of a particular scenario, conscience was determined by the law of man, for St German the common law. In those situations, there was no justification for Chancery intervention, indeed such intervention would be illegitimate. St German's theory therefore explained the need for the Chancery as a court of conscience, but circumscribed it. Equity and conscience could not extinguish the common law, indeed were predicated upon its existence. Equity was to remain an ancillary to the common law.

\section{THE ROLE OF RELIGION IN St GERMAN's JURISTIC WORK}

The influence of Christianity on Doctor and Student is both obvious and profound.

First, St German's principal sources for his legal theory, including his theories of equity and conscience, are medieval theology, principally the writings of the earlyfifteenth century French theologian Jean Gerson and Thomas Aquinas. There is also considerable use of the Summa Rosella and the Summa Angelica, books written for confessors to aid in confession and absolution. 
Second, Doctor and Student is in the form of a dialogue, a dialogue which itself reveals more about the interaction between law and religion in St German's thought. A point which is obvious, but perhaps so obvious that it is usually overlooked, is that Doctor and Student is a dialogue between a Student of the common law (meaning a barrister) and a Doctor of theology. A useful comparison is William Fulbeck's Parallele. ${ }^{43}$ The Parallele is another dialogue about law involving a barrister which discusses various issues casuistically. The participants in Fulbeck's dialogue, however, are all lawyers: a common lawyer, a civil lawyer and a canon lawyer. The only comparable work to Doctor and Student as a dialogue which moves beyond the world of law in a narrowly conceived way is Thomas Hobbes's Dialogue...of the Common Laws of England, where a common lawyer and a philosopher (no longer a theologian) engage in debate. ${ }^{44}$ St German's work is consequently not narrowly legal and law is not a discipline strongly separated from others.

Crucially, in Doctor and Student, it also becomes apparent that law and theology are sufficiently similar that the Student and the Doctor can understand one another and can reach conclusions in the other's discipline. The two disciplines were not identical, but were related. For example, when discussing the law of reason in England, the Doctor explains that he wishes to know about the law of nature in English law. The Student explains that English lawyers do not use the language of the law of nature, instead 'when anything is grounded upon the law of nature: they say that reason will that such a thing be done'. The Student considers this difference to be essentially terminological, a question of what common lawyers say, rather than what they mean, and the Doctor does not disagree. The Doctor subsequently asks for an example of the law of reason secondary particular. The Student poses a case and asks for the Doctor's view. Having heard this, the Student informs the Doctor that

\footnotetext{
${ }^{43}$ William Fulbeck, A Parallele or Conference of the Civill Law, the Canon Law, and the Common Law of this Realme of England (1601, London, Thomas Wight).

${ }_{44}$ Thomas Hobbes (Alan Cromartie and Quentin Skinner (eds.)), Writings on Common Law and Hereditary Right (2005, Oxford, Oxford University Press).
} 
'you have given a true judgment'. ${ }^{45}$ The Student can communicate English legal theory to the Doctor, and the Doctor can reach conclusions in English law when provided with the relevant information. If lawyers are priests, as the ius commune and John Fortescue claimed, for St German priests could equally be lawyers.

These observations make clear that religion was clearly an influence on Doctor and Student. However, a better understanding of Doctor and Student views the work as a more thoroughly religious one, even a work with a religious purpose, containing juristic elements. This is best seen by examining aspects of the work which are largely overlooked or ignored, as not directly relevant to legal historians or those concerned with the Henrician Reformation.

\section{Doctor and Student as a Religious Work}

Several aspects of Doctor and Student suggest that we should understand the work as one directed to religious ends, rather than secular ones.

\section{(1) What was Doctor and Student?}

The first, neglected, issue is what we mean by Doctor and Student. It is conventional to identify as Doctor and Student three works: the 1528 Latin dialogue on the grounds of the laws of England and conscience and its subsequent English versions, when it is described as the 'First Dialogue'; the 1530 Second Dialogue; and the 'New Additions' to the Second Dialogue, printed in 1531. However, there is a fourth work by St German which continues the dialogue between the Doctor of Theology and the Student of the Common Law. This unprinted work was sent by St German to Thomas Cromwell and is entitled 'A Dialogue showing What we be bound to believe as things necessary to salvation and what not' ${ }^{\prime}{ }^{46}$ This last work is clearly directed to

\footnotetext{
45 Doctor and Student, pp.31-37.

46 TNA: PRO SP 6/2, pp.89-168.
} 
religious ends and is really a work of theology, in which St German sets out his religious epistemology and conclusions on various matters of faith.

If all four of these works are what St German would, near the end of his life, have regarded as the complete Doctor and Student, then to regard Doctor and Student as solely a juristic work simply cannot be correct. The final dialogue shows a clearly religious purpose directed not to this world, but the next. The Student here is concerned not with the laws of England, but with his soul. ${ }^{47}$

It may be that this premise is wrong, and that St German would not have treated these works as related. On this analysis, St German presumably reverted to the dialogue with which he was familiar and by which he seemed to have made his name in one of his final works. But such an analysis seems weak. First, St German did treat Doctor and Student as an ongoing work in the early 1530s, making additions to the Second Dialogue after its initial publication. It is quite plausible to see subsequent work using the Doctor and the Student to be taking the original dialogue further, rather than a new departure. Second, St German's more controversial writings from the 1530s show a willingness to write outside the dialogue form, and in Salem and Bizance, St German wrote a dialogue with new characters to frame the work itself. The choice to go back to a dialogue between the Doctor of theology and the Student of the laws of England was a deliberate one, and the inference has to be that St German saw his final dialogue as related to the earlier discussions between those characters. That points to an understanding that those earlier discussions were not simply directed to worldly concerns, a conclusion which is supported by aspects of the earlier dialogues.

\footnotetext{
${ }^{47}$ It is tempting to view St German as modelling this dialogue on Luke 10: 25, where a lawyer asked what was necessary for eternal life. In the dialogue, the Student of the law asks what it is necessary to believe for salvation.
} 


\section{(2) St German's Sources}

It is well-known that St German's principal sources for his theory, and much of the content of parts of Doctor and Student, derives from religious and theological works: the writings of Jean Gerson and Thomas Aquinas; the Summa Angelica and the Summa Rosella. These were not the only sources, but they are the dominant ones in both the First and Second Dialogues.

Historians have spent considerable time and energy tracing these influences on St German, but have not considered what the choice of these sources tells us about the purpose of St German's work. He did not, for example, look to civil or canon law literature for his work. If St German was writing a juristic work, such juristic sources would seem a more likely reference. All of St German's religious sources did contain canon and civil law material, but St German chose to read and cite religious books, not legal ones. The titles of the works of Jean Gerson which particularly interested St German are revealing: the Moral Rules (Regulae Morales); The Book on the Spiritual Life of the Soul (Liber de Vita Spirituali Animae); and On the Carthusian Rule of Abstinence from Meat (De Non Esu Carnium apud Carthusienses). ${ }^{48}$ These are works which evidently have legal content, but are directed to non-legal purposes, to morality, the spiritual life and the soul.

If St German began his reading before conceiving of Doctor and Student as a project, then St German's interest was in religion, not law. If St German conceived of his project and then began research, he thought that religious works would provide what he needed. Either of these positions, and anywhere between them, suggests religion was a crucial element in St German's view of his project.

\footnotetext{
${ }^{48}$ Rueger, 'Gerson's Concept of Equity', pp.8, 11-12 and 16-19.
} 
A related consideration is the extent of St German's use of Jean Gerson. Gerson was a considerable and reputable theologian, so in that sense St German's reliance upon him is uncontroversial. But literature by theologians was not in short supply in latemedieval Europe, so why did St German chose this particular theologian as his principal theoretical source? One possibility, which cannot be discounted, is that Gerson's generous use of equity in his theology was suitable for St German's juristic project. $^{49}$

Another possibility places St German into a different historical context. St German is often treated by historians as providing a theory for the Chancery, or as an important element in the Henrician Reformation, his writings providing intellectual legitimacy to the break from Rome. Rather than focusing on how St German's work has been received, or on what occurred after the publication of the First Dialogue in 1528 , looking at the situation before and at the time of the production of the First Dialogue gives a very different perspective. St German, seemingly a quite conservative individual, had the misfortune to live in interesting times. The obvious context is the European Reformation. England was not isolated from continental developments and there was English knowledge of the religious turmoil on the continent. The Church was divided. There clearly was some anti-clericalism in Henrician England, particularly visible in the Richard Hunne affair and its aftermath, an event with which St German may have had a tenuous personal connection. ${ }^{50}$

Richard Hunne was sued in the church courts by the priest who had buried his five week old son. The priest claimed the baby's christening robe as a customary

\footnotetext{
${ }^{49}$ Aquinas, for example, had a more restricted view of the acceptable use of equity, limiting it to exceptional situations and placing it under the control of the ruler (Rueger, 'Gerson's Concept of Equity', p.14).

${ }^{50}$ The wardship of Richard Hunne's daughters was granted to John Rastell (Alan Harding, 'Rastell, John (by 1468 - 1536), of London' in S.T. Bindoff (ed.), The House of Commons 1509-1558 (1982, London, Secker and Warburg), vol.3, p.177), who was linked with St German (above, n.24).
} 
payment, a mortuary, in the church courts. Hunne, who was already involved in litigation with the church, began proceedings for praemunire in the King's Bench, alleging that the church court was the imposition of a foreign power in England. The church responded by investigating Hunne for heresy. Hunne was imprisoned, found hanged in his cell and a coroner's jury found foul play, rather than suicide. The case was an extreme example, but allegations of praemunire in relation to cases arguably concerned with secular rights were not unusual in the common law courts in the late-fifteenth and early-sixteenth centuries. ${ }^{51}$ The common law courts could be a route for voicing dissatisfaction with, and challenging, the Church.

For someone who clearly was concerned about religious matters, these issues would have mattered to St German. His own anti-clericalism is quite clear, but so is his sincere religious belief. St German may have been concerned, quite plausibly, that divisions between the laity and the clergy might pave the way for division in the Church. St German did seek to address this issue in other writings; his Treatise concerning the Division is directed to the causes of, and solutions to, just such a division. If this interest existed before the early 1530s, as is perfectly plausible, an interest in, and reliance upon, Gerson becomes very readily explicable. Gerson was in many ways a theologian of the Great Schism, many of whose writings were directed at identifying a way to resolve the divide in the Church. Gerson's prescriptions included an accurate understanding of legal theory with the consequence that many aspects of canon law were not divine law. ${ }^{52}$ Just such a theory could address some of the dissatisfaction in England, curbing what St German perceived as clerical abuses. For example, Gerson and St German would both reject questions of payment, such as that sought by the priest when claiming the mortuary in Hunne's case, as being subject to spiritual sanction, as when the priest brought proceedings in the church courts. Doctor and Student's discussion of

\footnotetext{
${ }^{51}$ Baker, Oxford History, pp.237-243.

${ }^{52}$ See generally, Louis B. Pascoe, Jean Gerson: Principles of Church Reform (1973, Brill, Leiden), pp.49-79.
} 
Chancery provided legitimacy for the jurisdiction of the clerical Chancellor, provided that Chancery kept within certain bounds.

\section{(3) Equity and Conscience in Doctor and Student}

The discussion of equity and conscience in Doctor and Student has typically been associated with the Chancery jurisdiction, which came to be known as equity. Relief from the Chancery had increased in importance through the fifteenth century, and Wolsey's tenure as Chancellor was controversial. St German's elaboration of conscience in the First Dialogue clearly had the potential to provide a theory for that jurisdiction and explain why clerical chancellors needed to respect the common law and in many instances allow the decisions of common law courts.

However, this focus on the Chancery does not easily flow from Doctor and Student itself. The Chancery is considered, but is rarely the focus of the discussion. As John Guy has observed, for St German's detailed consideration of the Chancery and its activities we need to look at his Little Treatise on Writs of Subpoena, not Doctor and Student itself. ${ }^{53}$ The Little Treatise was first printed in 1787 and while it is dangerous to infer too much from the unprinted state of any early-modern work, the fact that St German printed several other works at around the time the Little Treatise was written may indicate that he could have printed it, had he wished to do so. Legal printing in the reign of Henry VIII was dynamic and a successor to the frequently reprinted Doctor and Student would probably have sold well. Market explanations for the manuscript status of the text seem improbable. Guy suggests that the manuscript was unprinted because St German 'became involved in other things' ${ }^{54}$ This does not seem especially convincing; St German had not become so involved elsewhere that he was uninterested in writing on the topic. An alternative explanation may be that St German did not think the Chancery debate was that important - interesting, but

\footnotetext{
${ }^{53}$ Guy, St German on Chancery and Statute, p.64

${ }^{54}$ Guy, St German on Chancery and Statute, p.57
} 
not important. He was interested in Chancery as a court of conscience, but his principal concern was not the practice of the Chancery itself.

This provokes consideration of why St German was interested in conscience. There are good reasons for believing that St German's predominant concern was not with conscience as applied in the Chancery, but individual conscience, perhaps as affected by confession and even the church courts.

Most obviously, the English version of Doctor and Student sometimes uses the language of 'conscience' when the Latin equivalent, 'conscientia', is absent. Instead, the original Latin of the First Dialogue suggests a concern with the internal forum, rather than any application of conscience in the courts. Where the English at one point refers to laws made by men binding 'and that in conscience', the Latin is 'etiam in foro anime', suggesting a concern with the individual's soul. ${ }^{55}$

Doctor and Student also includes discussions of situations where Chancery provides no remedy. This is obviously important when considering the jurisdiction of any court. But St German goes on to consider what ought to happen despite the absence of a Chancery remedy. At such points St German is not concerned with conscience in Chancery, but the conscience of the individual. Simply because the Chancery does not intervene on the grounds of conscience does not mean conscience has no role.

A particularly good example of this is found in the Second Dialogue, where three questions by the Student are directed not to what the outcome in conscience of facts ought to be, but whether a lawyer, knowing all the facts, and understanding that the outcome in conscience would be different to that in law, could in conscience 'be of

\footnotetext{
${ }^{55}$ Doctor and Student, pp.146-147. The weight of evidence suggests that St German was the composer of the original English text, although this is disputed (see Barton, 'Introduction', pp.xvi-xviii).
} 
counsel' for the party right in law but wrong in conscience. ${ }^{56}$ These are not questions of Chancery remedies, but of professional ethics. They are not about correcting the conscience of the litigant, but ensuring conscientious action by lawyers. ${ }^{57}$

In one of the cases, while the Chancery is mentioned, the real issue is the conscience of the lawyer placed in the invidious position of a difference between law and conscience, asked to act at law: 'whether may a man with conscience be of counsel with the plaintiff in an action at the common law knowing that the defendant has sufficient matter in conscience whereby he may be discharged by a subpoena in the Chancery which he cannot plead in the common law or not' ${ }^{\prime 8}$ St German clarifies the example as that of the paradigmatic case of double recovery of a debt on a bond. Could a lawyer, for example, act to recover a debt in the common law courts which had already been paid, but where there was no written acquittance, the only acceptable proof of that payment?

As with the other cases, it is clear that the lawyer should not act against conscience. In this particular instance, however, the Student replies by observing that serjeants at law were 'sworn to give counsel according to the law...it seems he is bound to give counsel according to the law, for else he should not perform his oath.' Conscience required this lawyer not to act, but his sworn oath seemed to require him to do so. Oath-taking, and breaches of oaths was taken very seriously in Henrician England as a matter of individual conscience, with breaches of oaths placing one's soul in jeopardy. ${ }^{59}$ This lawyer was consequently in a particularly difficult position. The difficulty, however, was not one for any court. This was a matter for the internal forum, the individual's own conscience and perhaps ultimately sin, repentance and

\footnotetext{
${ }^{56}$ Doctor and Student, pp.187-192.

57 See also Doctor and Student, pp.215-217 concerning inaccurate legal advice and p.285, where St German refers to the conscience of judges.

${ }^{58}$ Doctor and Student, pp.189-190.

${ }^{59}$ See, e.g., Jonathan Michael Gray, Oaths and the English Reformation (2012, Cambridge, Cambridge University Press).
} 
penance through the Church. The Doctor finds a solution to the problem; the serjeant's oath to give counsel according to law includes according to the 'law of god and the law of reason', both of which the Student had earlier enumerated as part of the laws of England. Acting to claim the debt for a second time would contravene both of these laws and so the serjeant is not bound by his oath to do so, indeed is bound by his oath not to act.

This discussion is clearly not directed to the Chancery, but to the lawyer's own individual conscience. Similarly, in the First Dialogue, St German elaborates several situations where someone 'shall not be punished...by the law'. Instead he is 'bound in conscience to reform if he will save his soul', that judgment applying only 'to his conscience' ${ }^{60}$ Like the discussion of the lawyer, conscience here is personal, directed to the conscience of the wrongdoer, not conscience as applied in the Chancery. St German's analysis of these situations seems to reduce the need for the Chancery. If lawyers acted in accordance with conscience, then cases where they knew of reasons for Chancery intervention would not be brought in the common law courts at all. ${ }^{61}$ The Chancery would then not need to intervene. If individuals acted in accordance with their conscience, there would be no need for Chancery intervention. For St German, attention to individual conscience therefore obviates the need for Chancery.

This concern with individual conscience in the internal forum, rather than the imposition of conscientious outcomes through courts is identifiable in other aspects of Doctor and Student. Most obviously, this can be seen in the neglected prologue to the 1528 Latin printing, a text which was not included in the English editions. St German explains that one of his purposes in the First Dialogue (perhaps the only part then written) was 'to incite others to collect and put into writing additional

\footnotetext{
${ }^{60}$ Doctor and Student, p.113.

${ }^{61}$ Of course this does not address the situation where a lawyer is unaware of the reasons for Chancery intervention when acting in the common law courts.
} 
cases in English law upon which conscience ought to be based'. St German wanted more English law cases to be written, because conscience ought to be based on such cases. He then explained that 'the knowledge of which is necessary not only for the rendering of justice in the king's courts, but also for leading all those who heed them in the internal forum to a good and healthy conscience' (emphasis added). ${ }^{62}$ St German makes it quite clear here that his work is not simply directed to the courts, but to the internal forum too.

In fact, the internal forum was probably more important. According to St German in the preface, the First Dialogue was published in Latin 'for the greater ease of those who know that language'.$^{63}$ Assuming this is true, it is safe to infer that St German sought a wider audience than common lawyers, whose literature was usually in lawFrench. A Latin text would be available to the clergy (including the clerical Chancellor) and educated laypeople. Such audiences did not need to know the intricacies of common law for their own purposes, and most did not need to know about the Chancery. But they did need to know about conscience and about sin.

Once St German reached the conclusion, which he states in the preface, that English law informs, even governs, many aspects of conscience, then English law in its relation to conscience does need to be published 'for the good direction of conscience in this realm'. The preface makes it clear - Doctor and Student began as a book about directing conscience. That conscience was relevant to lawyers, and it was relevant to the Chancery, but it was also relevant to everyone else in England. St German even ends the Latin First Dialogue making just this point. The final word goes to the Doctor, who says 'I will make a greater effort than I have so far made to gain a fuller acquaintance with English law, for it is clear that a knowledge of it is highly

\footnotetext{
${ }^{62}$ Doctor and Student, p.3.

${ }^{63}$ Doctor and Student, p.3.
} 
necessary, even in matters of conscience, to clerks and laymen, and to all who dwell within this realm'. ${ }^{64}$

The Second Dialogue continues this theme. Twenty chapters (of fifty five) in the Second Dialogue raise issues which are taken explicitly from the Summa Angelica and Summa Rosella, confessional manuals concerned with sin, albeit with considerable legal influences. ${ }^{65}$ These confessional questions were also legal, ranging from the rules about appointments of priests to benefices (the right to appoint being a type of property right known as an advowson in medieval English law), to whether a landowner can seize animals trespassing on his land and doing damage to it or who should bear the loss if without fault a house falls on a borrowed horse. ${ }^{66}$

An obvious question is why St German chose to discuss these questions. He could simply have been identifying differences between the common law and the ius commune tradition, much in the way that Fulbeck did in his later Parallele. But St German was doing much more than this. He seems to have been concerned that people may be reading the Summae to provide them with guidance as to what they ought do in conscience, or what they as confessors should do in relation to the consciences of their charges. This was not implausible: Thomas More was able to use St German's reliance on the Summa Rosella in his later anonymous writings to suggest that the author was a parish priest, rather than a barrister. ${ }^{67}$

From St German's perspective, because the Summae relied upon the incorrect temporal law in answering these questions, they gave the wrong answers to questions of conscience which depended upon matters of law. As St German's

\footnotetext{
${ }^{64}$ Doctor and Student, p.153.

${ }^{65}$ Doctor and Student, pp.237-279. The final of these chapters (chapter forty five) is itself a list by the Student of over forty further questions from the Summae which require reconsideration!

${ }^{66}$ Doctor and Student, pp.239, 243-245, 254-259 (all on presentments), 240-241, 259-261.

${ }^{67}$ J.B. Trapp, 'Introduction' in Trapp, Complete Works, vol.9, p.xxxix.
} 
Student observed, there was no fault on the part of the authors of the Summae, 'for they have thereby given a right great light in conscience to all countries where the law Civil and the law Canon be used to temporal things. But as for the laws of this realm they knew them not...if they had known them it would little have helped for the countries that they most specially made their treatises for'. Conscience was in many cases governed by the temporal law of a particular jurisdiction, so St German instead marvelled 'greatly that none of them that in this realm are most bound to do that in them is to keep the people in a right judgement and in a clearness of conscience: have done no more in time past to have the law of the realm known than they have done'. ${ }^{68}$ The Second Dialogue, printed in English, served to correct this failing on the part of the English clergy to explain English law in relation to English conscience. Comparative law became comparative conscience and thinly-veiled anticlericalism. St German, a layman and lawyer, provided a guide to conscience in English to the people of England. This criticism of the clergy's failure suggests a lay audience; this is confirmed by the introduction to the Second Dialogue. ${ }^{69} \mathrm{St}$ German's guide to conscience was not for confessors, but the laity; the prevention of sin rather than the cure of souls.

This analysis of St German's purpose in Doctor and Student suggests greater coherence with his other works appearing shortly after 1530 than an understanding focused directly on the Chancery or the Break from Rome. It is evident in the New Additions and the Parliamentary Draft that St German was interested in Parliament's role to intervene in Church matters not for its own sake, but to ensure that priests better performed their roles. This is precisely the concern which lay behind his discussion of conscience and is raised expressly in the Second Dialogue.

\footnotetext{
${ }^{68}$ Doctor and Student, p.275. Similarly p.131.

${ }^{69}$ Doctor and Student, pp.176-7.
} 
St German's discussion of conscience, directed to the laity, had a further, dramatic consequence. It fundamentally undermined any claims by the European Church to knowledge and expertise in conscience. The Church could claim such expertise in relation to St German's narrowly defined laws of God and Nature, but many questions of conscience, as St German showed, were determined not by universal law but by local law. Conscience had become geographically diverse. For St German, writing in the midst of the Reformation, there was no unity of Christendom in questions of conscience and for the Church to claim such universality risked leading people into error and sin.

\section{CONCLUSION: ST GERMAN THE CHRISTIAN JURIST}

Doctor and Student contains much that was relevant for equity and Chancery and for the Henrician Reformation. Such material appears in much of the text. The pervasiveness of religion to medieval and early-modern life and thought means that religious works were also often works of law or political theory. The argument is that substantial parts of Doctor and Student are best understood through a religious lens, and that religion, in particular the guidance of the conscience of individuals, was a prominent purpose in the text. Whatever his later importance and reputation, in much of Doctor and Student St German was more concerned with the soul than the subpoena. 
Primary Sources (all with helpful introductions)

Guy, J.A., Christopher St German on Chancery and Statute (1985, London, Selden Society Supplementary Series Volume 6)

Plucknett, T.F.T and Barton, J.L. (eds.), Christopher St German's Doctor and Student (1974, London, Selden Society Series Volume 91)

St German, C., A Treatise Concernynge the Division Betwene the Spirytualtie and Temporaltie, pp.177-212 in J.B. Trapp (ed.), The Apology of Sir Thomas More, Knight (1533), vol.9 in The Complete Works of St. Thomas More (1979, New Haven, Yale University Press)

St German, C., Salem and Bizance, pp.325-392 in J. Guy, R. Keen, C.H. Miller and R. McGugan (eds.), The Debellation of Salem and Bizance, vol.10 in The Complete Works of St. Thomas More (1987, New Haven, Yale University Press)

Secondary Sources

Guy, John, 'Thomas More and Christopher St German: The Battle of the Books', pp.95-120 in Fox, Alistair and Guy, John, Reassessing the Henrician Age: Humanism, Politics and Reform 1500-1550 (1986, Oxford, Basil Blackwell)

Kelly, Henry Ansgar, ‘Thomas More on Inquisitorial Due Process' (2008) 123 English Historical Review 847-894

Rueger, Zofia, ‘Gerson's Concept of Equity and Christopher St. German' (1982) 3 History of Political Thought 1-30 